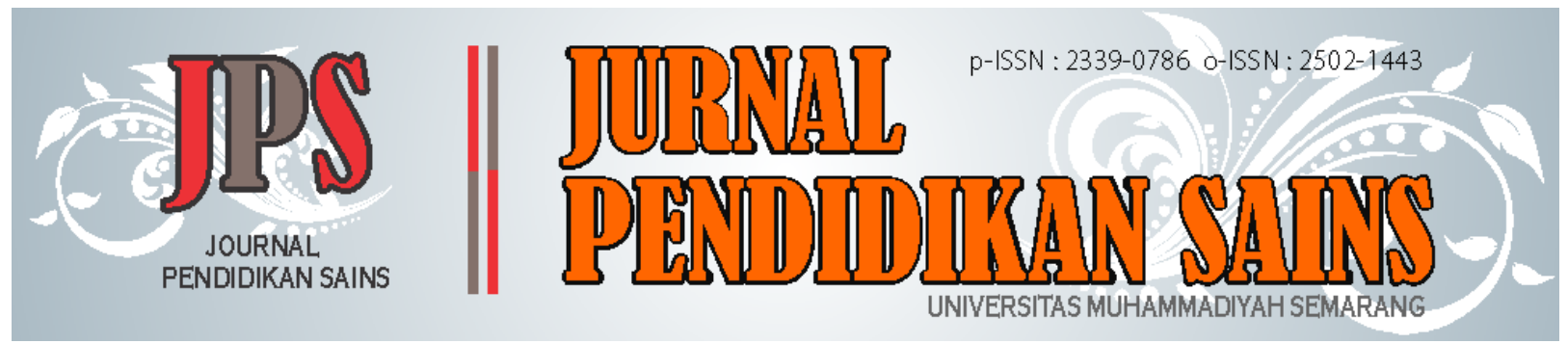

$\underline{\text { http://jurnal.unimus.ac.id/index.php/JPKIMIA }}$

\title{
Problem Base Learning Virtually In Blended Learning Model For Chemistry Lessons During The Covid-19 Pandemic
}

\author{
Nurin Fitriana ${ }^{\mathrm{a}, 1^{*}}$, Febi Dwi Widayanti ${ }^{\mathrm{b}, 2}$, Bayu Firmanto ${ }^{\mathrm{c}, 3}$ \\ ${ }^{\text {a,b,c } W i s n u w a r d h a n a ~ U n i v e r s i t y, ~ M a l a n g, ~ I n d o n e s i a ~}$ \\ $\underline{1}$ nurin.unidha@gmail.com * ${ }^{2}$ febidwi07@gmail.com, ${ }^{3}$ bayufirmanto@gmail.com \\ *corresponding author
}

\begin{abstract}
Article History
Submission : 2020-11-27 Learning from home became one of the government's policies to overcome the

Revised : 2021-01-25 Covid-19 pandemic that hit Indonesia and even the world today. It becomes the

Accepted : 2021-02-16 foundation of learning activities that require internet technology so that learning objectives continue to run and are achieved. Online learning must be well planned to be still student-centered who can construct their knowledge with contextual abilities.

Keyword: Problem Base Learning Virtually (PBL-V) is one model that can be implemented in

Blended learning

Chemistry lessons

Problem Base Learning

Virtually exploring student understanding. This type of research is quantitative descriptive with data collection techniques through a questionnaire using a Likert scale. The questionnaire has been tested for the validity of the Pearson Product Moment Correlation. The results of this assessment indicate a favorable response strongly agreed as much as $53 \%$ of the use of PBL-V in the learning activities of the chemistry lessons. As many as $63 \%$ of students expressed strongly agree with blended learning composition offline: online 10:90. Offline learning activities are carried out to consolidate concepts in student constriction, which is carried out before the social restriction regulations are carried out online so that learning objectives still be achieved during the Covid-19 pandemic.
\end{abstract}

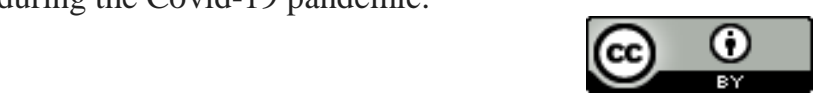

This work is licensed under a Creative Commons Attribution 4.0 International License

C2021 Jurnal Pendidikan Sains Universitas Muhammadiyah Semarang

\section{INTRODUCTION}

Recently, various countries in the world have been shocked by the outbreak of a disease caused by the coronavirus or better known by the public as Covid-19, which stands for Corona Virus Diseases19. This virus attacks the respiratory system. The disease caused by infection from this virus is called Covid-19. Coronavirus causes disorders of the respiratory system, acute pneumonia, and even death. This virus initially began to develop in Wuhan, China. This virus outbreak is indeed very fast and spreads almost worldwide, so the World Health Organization (WHO) states that the outbreak of the Covid-19 virus is called a pandemic.

The spread of this virus is one of the causes of the highest death rate in various countries in the world, including Indonesia. Indonesia has also received the impact of the spread of this virus. From day to day, the spread of this virus is getting faster in many regions in Indonesia. Many of the victims died, even many from the medical personnel. This is a problem that must be faced by the world today in implementing various policies, including in Indonesia. 
For the common good, the Minister for State Apparatus Empowerment and Bureaucratic Reform (Minister PAN-RB) issued a new circular stating that there are activities of working from home (Work From Home) and adjustments to the work system. The existence of this policy is one of the efforts applied to the community so that they can complete all work at home. The scope of education is one of the aspects affected by the Covid-19 pandemic with the limitation of interaction.

The Ministry of Education in Indonesia has issued a policy to close the education unit and replace the Teaching and Learning Activities (KBM) process by using online or online learning. The internet is currently very much needed by all groups, especially students (Hermawan et al., 2017). Using an online or online learning system, there are usually various problems faced by students and teachers. For example, the teacher has not completed learning materials, and then the teacher replaces them with other assignments. This is a complaint about students because the assignment given by the teacher is more. Distance education or can also be referred to as distance learning. Almost all education actors make it one of the learning solutions in dealing with the Covid-19 pandemic outbreak (Kusuma \& Hamidah, 2020).

We need to instill in ourselves that students in the era and post-pandemic, which young people dominate, can have faster access to technology and content than previous generations. Online learning is one of our efforts to facilitate and develop post-pandemic learning performance. The development of lifebased learning implies dynamic changes in people's lives after the pandemic (Praherdhiono, Henry, 2020). The efforts made by the teacher in teaching at this time are essential so that learning feels exciting and not dull. The characteristics of abstract chemical concepts also cause chemistry to be considered difficult by most students (C. Wulandari, 2018).

Based on the characteristics of chemical materials, it is necessary to create a learning model to construct their understanding. It is essential to include contextual values to understand self-based learning by applying attractive learning models. One of them is problem-based learning (PBL), which is a learning model that exposes students to real-world problems to start learning. Besides, the purpose of PBL is to encourage cooperation between students in completing tasks. In an investigation that allows students to understand and explain learning activities related to phenomena in the real world, besides that, it also involves the three domains (cognitive, affective, and psychomotor) in a balanced way, besides that it can build learners' optimism that a problem is something that must be solved, not avoided. . Problem Based Learning (PBL) is not structured to assist teachers in conveying a lot of information but teachers as problem presenters, questioners, and facilitators (Tany \& Utami, 2006).

During a pandemic, when learning must use online classes, educators must think about the teaching and learning process in a virtual way, so it is necessary to design a Problem base learning virtually (PBL-V) learning in Blended Learning. Blended learning utilizes various technologies that can improve the learning process and results as a learning medium (Fitriana, 2018).

Problem Based Learning is a learning model that demands students' mental activity to understand a concept through the situations and problems presented at the beginning of learning to train students to solve problems (N. I. Wulandari et al., 2018). The results of other studies show that the problem-based learning model is effective and has a large measure of influence in improving students' flexible thinking skills on acid-base material (Sari, Anggun Purnama, Ratu Betta Rudibyani, 2018). The results of other studies indicate that there is a significant difference between the learning outcomes of students who are taught the PBL model using the real lab and the PBL model using the virtual Chemlab on acid-base titration material(Sulistiowati et al., 2017). Problem-based learning (PBL) is a learner-centered pedagogy in which learners learn about a subject by trying to find solutions to open problems (Phungsuk et al., 2017). One of the learning activities during pandemic conditions is using online learning, known as online or virtual classes. In maximizing the process of understanding students in constructing their abilities, they can use a learning model in the form of PBL. Thus it is necessary to do PBL-V learning to facilitate chemistry learning activities.

\section{METHOD}

This type of research is descriptive quantitative research. Quantitative research emphasizes the ethical approach, namely data collection, by first determining the concept as a related variable, then the indicators are assigned to these variables. After that, a questionnaire or questionnaire is made, and the answer choices and scores are made. Several descriptions that describe it can be used to find principles and explanations that lead to concluding. The sampling technique is generally carried out randomly; data collection uses research instruments (Sugiyono, 2015). The technique of collecting data through a questionnaire distributed to 40 students was analyzed using a Likert scale questionnaire. The 
questionnaire is a data collection method that is done by giving a set of questions or written statements to the respondent to be answered. The questionnaire is a more efficient data collection method if the researcher knows exactly which variable will be measured and what is expected from the respondent. The Likert scale has four or more question items that are combined to form a score/value that represents individual traits, for example, knowledge, attitudes, and behavior (Budiaji, 2013).

Table 1. Questionnaire Result Data Scoring

\begin{tabular}{lcc}
\hline \multirow{2}{*}{ Criteria } & \multicolumn{2}{c}{ Score } \\
\cline { 2 - 3 } & increased & decreased \\
\hline SS (strongly agree) & 5 & 1 \\
\hline S(Agree) & 4 & 2 \\
\hline B(Enough) & 3 & 3 \\
\hline TS (disagree) & 2 & 4 \\
\hline STS(Strongly & 1 & 5 \\
Disagree) & & \\
\hline
\end{tabular}

(Indrawan, 2017)

The questionnaire has been tested for the validity of the Pearson Product Moment Correlation, namely using the principle of correlating or linking each item score or question with the total score obtained from respondents' answers to the questionnaire. By comparing the value of the $r$ hierarchy to the $r$ table. If the value of $r$ count $>r$ table, then the item in the questionnaire is declared valid. Then the Sig. ( 2 tailed) $<0.05$ and Pearson Correlation is positive, so the questionnaire item is valid.

In this study, what is measured is the use of virtual problem-based learning in blended learning with the composition offline: online $=10: 90$. This composition is due to the conditions of online learning during the Covid-19 pandemic. Offline $10 \%$ of the total meetings before the enactment of Large-Scale Social Restrictions (PSBB) in the research area, after being implemented, online learning so that the total is $90 \%$ of the total meetings. Based on Table 1 above is obtained respondent data as many as 40 people and analysis of each question item in the questionnaire.

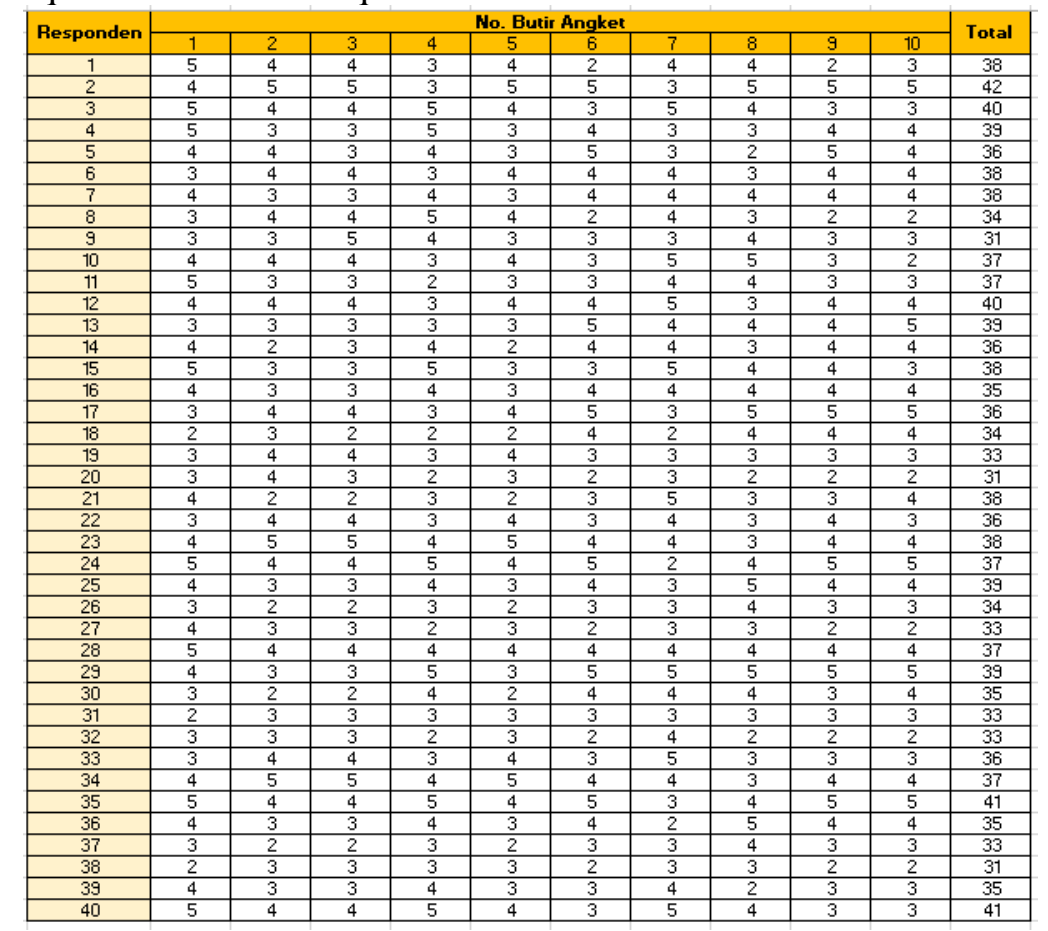

Figure 1. Respondent data on items in the questionnaire

In Figure 1, the data obtained from respondents as many as 40 people in the questionnaire given. The validity test is useful for determining the validity or suitability of the questionnaire used. Test the validity of the Pearson Product Moment Correlation using the principle of 
correlating or linking each item score or question with the total score obtained from respondents' answers to the questionnaire. The basis for taking is to compare the calculated r-value with the $r$ table value; if $r$ count $>r$ table, then the questionnaire item is declared valid, and vice versa. Besides, it can be seen from the significance value (2-tailed) $<0.05$ and the Pearson Correlation is positive, then the questionnaire item is valid, and vice versa.

In Figure 2 below, the results of the Bivariate Correlation Analysis from the data in the study.

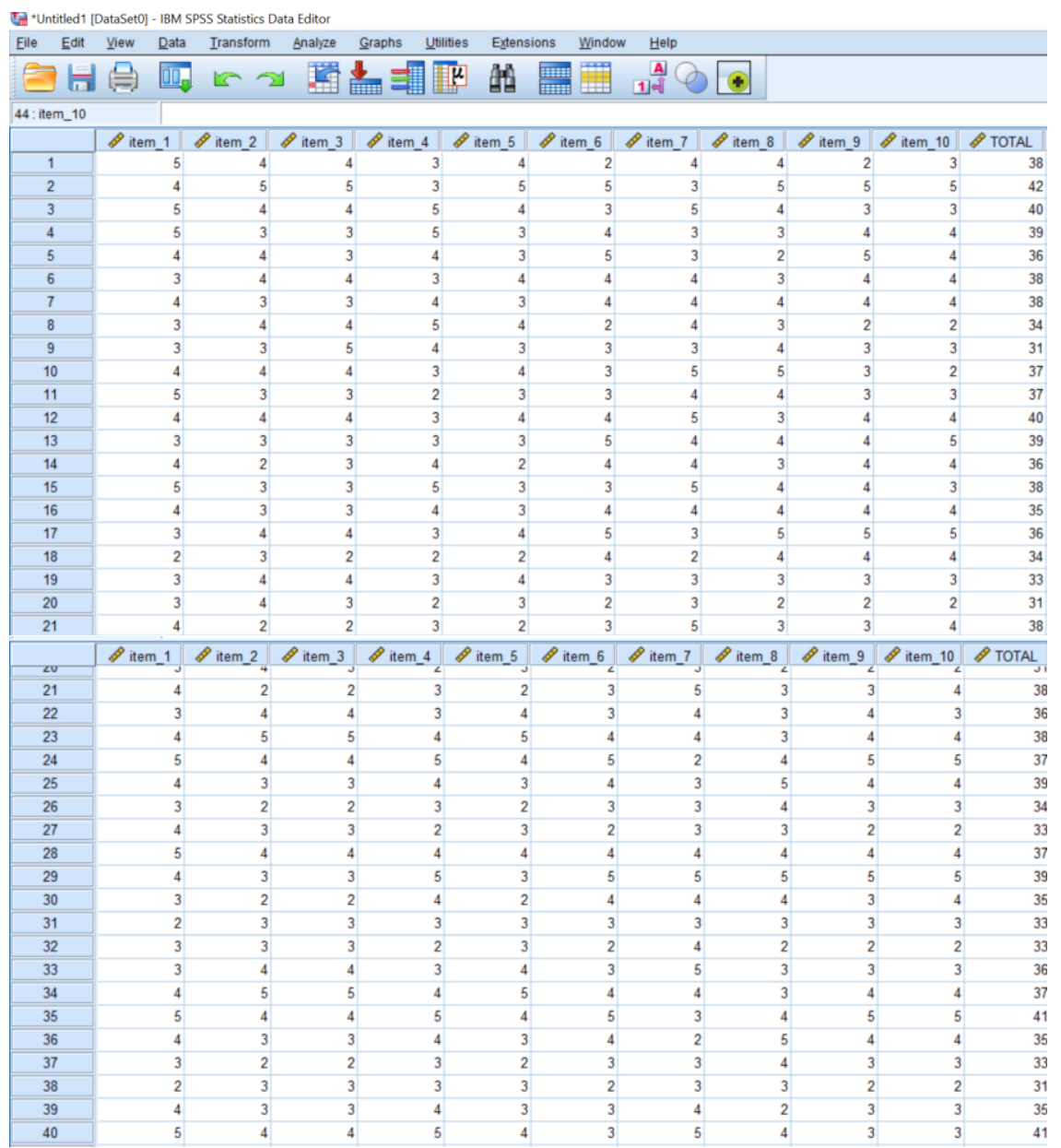

Figure 2. Analysis with SPSS

To find out the validity of the item in the questionnaire, a Bivariate Correlation Analysis was performed. The results are shown in Figure 3 below. 


\begin{tabular}{|c|c|c|c|c|c|c|c|c|c|c|c|c|}
\hline \multicolumn{13}{|c|}{ Correlations } \\
\hline & & item_1 & item_2 & item_3 & item_4 & item_5 & item_6 & item_7 & item_8 & item_9 & item_10 & TOTAL \\
\hline \multirow[t]{3}{*}{ item_1 } & Pearson Correlation & 1 & .219 & .245 & $.529^{\mathrm{Nm}}$ & .291 & .215 & .291 & .229 & .283 & .252 & $.665^{\prime \prime}$ \\
\hline & Sig. (2-tailed) & & .174 & .127 & .000 & .069 & .182 & .069 & .155 & .077 & .116 & .000 \\
\hline & $\mathrm{N}$ & 40 & 40 & 40 & 40 & 40 & 40 & 40 & 40 & 40 & 40 & 40 \\
\hline \multirow[t]{3}{*}{ item_2 } & Pearson Correlation & .219 & 1 & $.851^{\mathrm{m}}$ & .106 & $.948^{\mathrm{*}}$ & .167 & .075 & -.043 & .239 & .104 & $.349^{\circ}$ \\
\hline & Sig. (2-tailed) & .174 & & .000 & .514 & .000 & .304 & .645 & .790 & .137 & .523 & .027 \\
\hline & $\mathrm{N}$ & 40 & 40 & 40 & 40 & 40 & 40 & 40 & 40 & 40 & 40 & 40 \\
\hline \multirow[t]{3}{*}{ item_3 } & Pearson Correlation & .245 & $.851^{* \prime}$ & 1 & .229 & $.913^{\prime \prime}$ & .129 & .141 & .063 & .198 & .100 & .305 \\
\hline & Sig. (2-tailed) & .127 & .000 & & .155 & .000 & .428 & .385 & .700 & .221 & .539 & .056 \\
\hline & $\mathrm{N}$ & 40 & 40 & 40 & 40 & 40 & 40 & 40 & 40 & 40 & 40 & 40 \\
\hline \multirow[t]{3}{*}{ item_4 } & Pearson Correlation & $.529^{\prime \prime}$ & .106 & .229 & 1 & .191 & $.360^{\circ}$ & .179 & .221 & $.399^{*}$ & $.342^{*}$ & $.438^{\prime \prime}$ \\
\hline & Sig. (2-tailed) & .000 & .514 & .155 & & .238 & .022 & .269 & .170 & .011 & .031 & .005 \\
\hline & $\mathrm{N}$ & 40 & 40 & 40 & 40 & 40 & 40 & 40 & 40 & 40 & 40 & 40 \\
\hline \multirow[t]{3}{*}{ item_5 } & Pearson Correlation & .291 & $.948^{\prime \prime}$ & $.913^{\mathrm{m}}$ & .191 & 1 & .149 & .181 & .056 & .219 & .120 & $.427^{\prime \prime}$ \\
\hline & Sig. (2-tailed) & .069 & .000 & .000 & .238 & & .359 & .263 & .729 & .174 & .460 & .006 \\
\hline & $\mathrm{N}$ & 40 & 40 & 40 & 40 & 40 & 40 & 40 & 40 & 40 & 40 & 40 \\
\hline \multirow[t]{3}{*}{ item_6 } & Pearson Correlation & .215 & .167 & .129 & $.360^{\circ}$ & .149 & 1 & -.172 & $.411^{n \times}$ & $.943^{*{ }^{*}}$ & $.943^{* ”}$ & $.547^{\prime \prime \prime}$ \\
\hline & Sig. (2-tailed) & .182 & .304 & .428 & .022 & .359 & & .288 & .008 & .000 & .000 & .000 \\
\hline & $\mathrm{N}$ & 40 & 40 & 40 & 40 & 40 & 40 & 40 & 40 & 40 & 40 & 40 \\
\hline \multirow[t]{3}{*}{ item_7 } & Pearson Correlation & .291 & .075 & .141 & .179 & .181 & -.172 & 1 & -.060 & -.146 & -.146 & $.418^{\prime \prime}$ \\
\hline & Sig. (2-tailed) & .069 & .645 & .385 & .269 & .263 & .288 & & .713 & .368 & .368 & .007 \\
\hline & $\mathrm{N}$ & 40 & 40 & 40 & 40 & 40 & 40 & 40 & 40 & 40 & 40 & 40 \\
\hline \multirow[t]{3}{*}{ item_8 } & Pearson Correlation & .229 & -.043 & .063 & .221 & .056 & $.411^{\prime \prime}$ & -.060 & 1 & $.391^{*}$ & $.423^{* *}$ & $.385^{\prime}$ \\
\hline & Sig. (2-tailed) & .155 & .790 & .700 & .170 & .729 & .008 & .713 & & .013 & .007 & .014 \\
\hline & $\mathrm{N}$ & 40 & 40 & 40 & 40 & 40 & 40 & 40 & 40 & 40 & 40 & 40 \\
\hline \multirow[t]{3}{*}{ item_9 } & Pearson Correlation & .283 & .239 & .198 & $.399^{*}$ & .219 & $.943^{\text {"* }}$ & -.146 & $.391^{\circ}$ & 1 & $.882^{* *}$ & $.563^{\mathrm{m}}$ \\
\hline & Sig. (2-tailed) & .077 & .137 & .221 & .011 & .174 & .000 & .368 & .013 & & .000 & .000 \\
\hline & $\mathrm{N}$ & 40 & 40 & 40 & 40 & 40 & 40 & 40 & 40 & 40 & 40 & 40 \\
\hline \multirow[t]{3}{*}{ item_10 } & Pearson Correlation & .252 & .104 & .100 & $.342^{*}$ & .120 & $.943^{\prime \prime}$ & -.146 & $.423^{\prime \prime}$ & $.882^{\mathrm{m}}$ & 1 & $.592^{\prime \prime}$ \\
\hline & Sig. (2-tailed) & .116 & .523 & .539 & .031 & .460 & .000 & .368 & .007 & .000 & & .000 \\
\hline & $\mathrm{N}$ & 40 & 40 & 40 & 40 & 40 & 40 & 40 & 40 & 40 & 40 & 40 \\
\hline \multirow[t]{3}{*}{ TOTAL } & Pearson Correlation & $.665^{\circ}$ & $.349^{\circ}$ & .305 & $.438^{\prime \prime}$ & $.427^{\prime \prime}$ & $.547^{\prime \prime}$ & $.418^{\prime \prime}$ & $.385^{\circ}$ & $.563^{\mathrm{N}}$ & $.592^{\prime \prime}$ & 1 \\
\hline & Sig. (2-tailed) & .000 & .027 & .056 & .005 & .006 & .000 & .007 & .014 & .000 & .000 & \\
\hline & $\mathrm{N}$ & 40 & 40 & 40 & 40 & 40 & 40 & 40 & 40 & 40 & 40 & 40 \\
\hline
\end{tabular}

\section{Figure 3. Bivariate Correlation Analysis}

In SPSS, the data $r$ table for 40 respondents $=0.312$, so that Figure 4 is the conclusion of the analysis of the data obtained. There are ten questions in the questionnaire showing that the questions are valid and can be used as research references; the questions are given to explore student response information related to the Problem Base Learning Virtually in Blended Learning Model For Chemistry Lessons During The Covid-19 Pandemic.

\begin{tabular}{cccc}
\hline No.item & r (xy) & r (tabel) & Keterangan \\
\hline 1 & 0.615 & 0,312 & valid \\
\hline 2 & 0.349 & 0,312 & valid \\
\hline 3 & 0.305 & 0,312 & valid \\
\hline 4 & 0.438 & 0,312 & valid \\
\hline 5 & 0.427 & 0,312 & valid \\
\hline 6 & 0.547 & 0,312 & valid \\
\hline 7 & 0.418 & 0,312 & valid \\
\hline 8 & 0.385 & 0,312 & valid \\
\hline 9 & 0.563 & 0,312 & valid \\
\hline 10 & 0.592 & 0,312 & valid \\
\hline
\end{tabular}

Figure 4. the conclusion of the questionnaire validation 


\section{RESULTS AND DISCUSSION}

\section{Virtual Problem Based Learning (PBL-V)}

PBL-V is the development of the Problem Based Learning (PBL) learning model; its activities are based on virtual classroom learning. PBL is a learning module that initiates students by presenting a problem for the student to solve (Shofiyah \& Wulandari, 2018). Problems that will be faced by learners. It has two important characteristics, first, namely that the problem must be authentically related to the social context among students, the second problem must be rooted in the subject matter of the curriculum.

There are three main characteristics of PBL learning. First, problem-based learning is a series of learning activities, which means that in implementing PBL, there are several activities carried out by learners not only listening, taking notes, and then memorizing the subject matter, but through a problembased learning model (PBL), learners become active in thinking, communicating, looking for data and processing data, and finally making conclusions. Second, PBL learning activities are directed to solve problems. Problem-based learning places problems as the keywords of the learning process. This means that without problems, learning will not be possible. Third, there is problem-solving using a scientific thinking approach. Based on this, it is necessary to design a learning model that makes learning activities easier.

In online classes, PBL activities can be developed into PBL-V, which is a learning approach that presents contextual problems that stimulate students to learn online. PBL-V is a learning model that presents challenges for learners to learn, working in groups to find solutions to real-world problems.

In online or online learning, several applications can be assisted, such as Google Classroom, Edmodo, Zenius, Webex, Zoom, and so on, where their use allows learning activities to occur. Some of the steps in the PBL-V model carried out in this study are as follows:

Step 1: Student orientation to the problem, Explain learning objectives online. One of the programs that can be used through Google Classroom. At the beginning of the meeting, the content of problems related to learning can motivate students to be involved in the problem-solving activities they choose.

Step 2. Organizing students to learn. In the next online meeting, students define and organize learning tasks related to these problems in learning activities in Google Classroom.

Step 3. Giving contextual questions related to the material. At the next meeting, online through the Zoom application, teachers and students meet online to discuss the material presented.

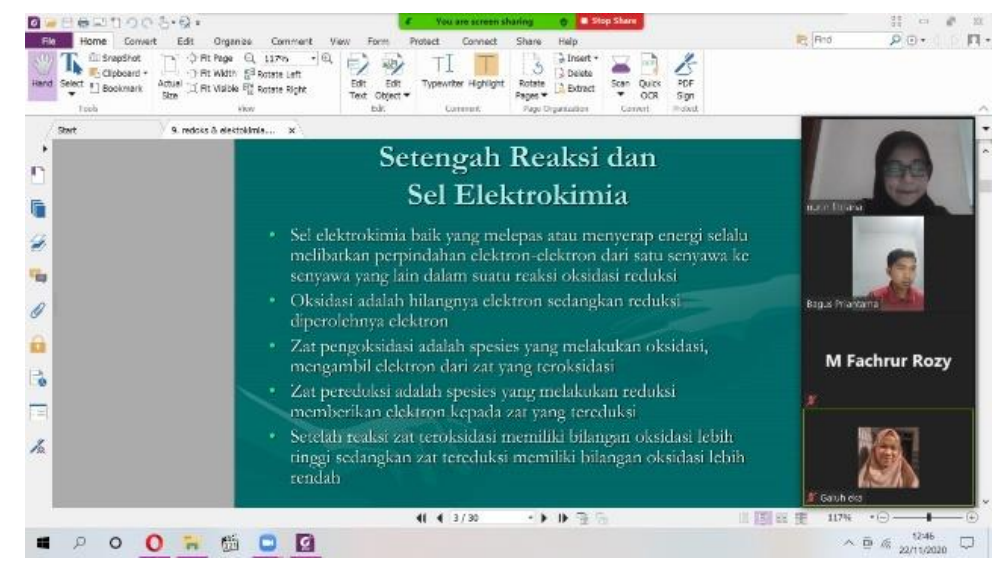

Figure 5. Explanation of material online with the Zoom Application

Figure 5 shows the learning online, namely using Zoom meeting media. Explanation of material to students, which allows for interaction between lecturers and students. 


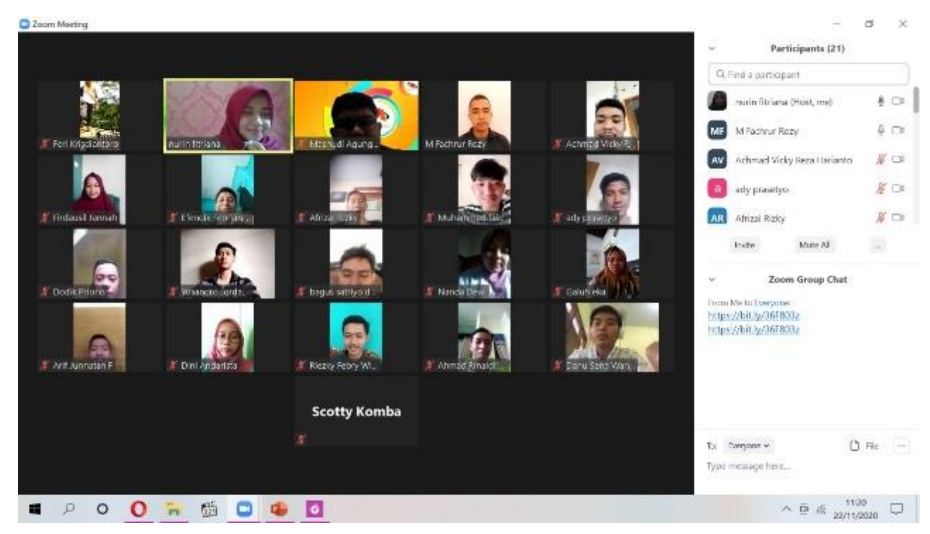

Figure 6. Virtual interaction with students using the Zoom application

Figure 6 shows the presence of students, which can be recorded by the lecturer so that they can find out the activity of each student. The utilization of the Zoom Meeting application is just done when this Social Distancing period requires students to study based online. (Haqien \& Rahman, 2020). By using the Zoom Meeting application, it can help students in terms of online and based learning students can make the most of this application maybe. Thus learning activities with the PBL-V strategy can stimulate student learning activities.

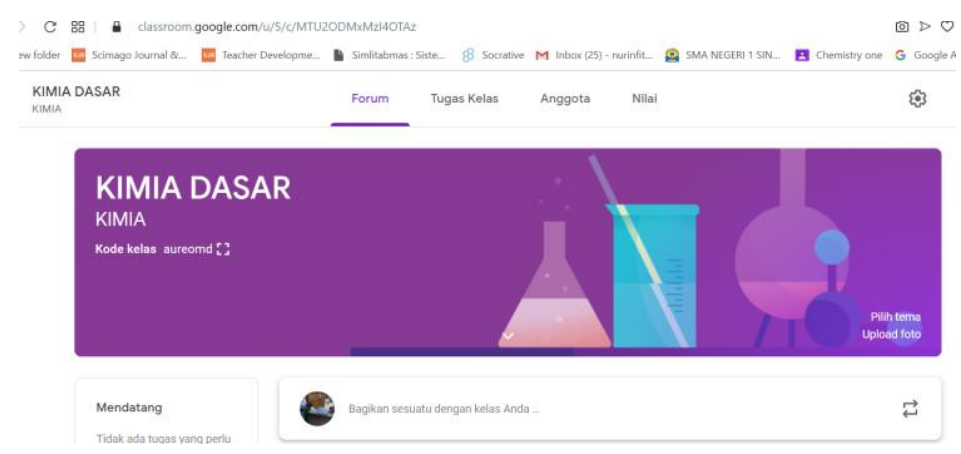

Figure 7. Aplikasi Google Classroom yang digunakan penelitian

Figure 3 is an online learning application, namely Google Classroom, which is one of the free accesses that makes it easier for lecturers in the e-learning process. Furthermore, this platform offers a lot of advantages for its users (Hapsari \& Pamungkas, 2019). Google Classroom has not been fully used, therefore to provide a policy to fully using Google Classroom for lecturers and students, it takes the right reasons to produce the right decision as well. (Wijaya, 2016). Also, this platform is known as a tool that is easy to use by smartphone or laptop users, as well as being able to create equal opportunities for all students and encourage students to learn more about internet literacy. Thus learning with problem-based learning in each sub-material can be easier.

Google Classroom is to offer a platform of blended learning in schools to simplify creating assignments and getting the grade out to the students in a paperless way. There are many facilities provided by Google classroom. They are: it will make it easier for teachers to carry out learning activities. The intended learning is not only in class but also outside the classroom because students can learn wherever and whenever by accessing google classroom online. (Sukmawati \& Nensia, 2019).

In PBL-V activities, learning is also carried out using the Zoom media, the Zoom meeting facility, which can provide great opportunities for students to discuss together related to the discussion of the material being studied. Researchers can also measure the depth of knowledge of each student. This can replace the face-to-face class, namely virtual video calls together in one class.

The use of google classroom and Zoom in online learning facilities is also good because it allows students to interact with teachers. The existence of several modes of learning activities in google 
classroom can help students construct knowledge independently by paying attention to learning instructions from the teacher.

\section{Purpose of the PBL-V Strategy}

Some of the goals that can be achieved in PBL-V learning are to encourage collaboration in completing tasks between students-in online classes, creating teaching and learning elements that encourage learning activities in student observation and dialogue with others, involving students actively, and being able to investigate their own choices. Allows them to understand and explain real-world phenomena involving the three domains, namely cognitive, affective, and psychomotor, to learners in a balanced manner. Thus the results can be remembered longer by students, can build students' optimism that a problem is something interesting to solve, not something to be avoided.

Based on this, it can be concluded that the learning process in the school environment has the same goal, which is to encourage the improvement of learning outcomes in students. Therefore, it is very necessary to have supervisors who can stimulate fun learning activities for learners.

In the PBL-V class, students will access more literature and make it easier to construct their knowledge independently. Virtual class based on problems given by the teacher to increase knowledge of teaching materials, you can find answers by accessing several references such as e-books, related scientific journals to practice questions that can be downloaded via the internet.

\section{PBL-V Blended Syntax}

In learning activities using Blended Learning carried out in this study with the composition of the meeting offline: online $=10: 90$. The implementation of the PBL-V model has the main steps that must be taken, namely the availability of learning programs that are used online. This study using Google Classroom facilities.

The learning syntax based on Virtual Problem Based Learning (PBL-V) is as follows:

1. The orientation of students to the problem

I was explaining the learning objectives, the learning process, and motivating students to be involved in the selected problem-solving activities. This is done via a column in Google Classroom.

2. Organizing students

In a virtual classroom, learners define and organize learning tasks related to the problem (assigning topics, assignments, etc.) through the discussion column. This is carried out when it is agreed that the lesson hours take place.

3. Guiding individual and group investigations

During the virtual class, learners collect information related to the material provided for problemsolving.

4. Develop and present the work

Students plan and prepare their work and collect it, then conduct virtual discussions online through the Google Classroom facilities used in learning.

5. Analyze and evaluate the problem-solving process

Students in reflecting or evaluating their investigations and the processes used through face to face online, one of which can be through Zoom meeting.

The main objective of PBL-V is not to convey most of the knowledge that is owed to students by providing knowledge during virtual learning but to develop students' critical thinking skills. The ability to independently construct their understanding and problem-solving abilities and at the same time developing students' abilities to actively build their knowledge (Desriyanti \& Lazulva, 2016). PBL-V is also intended to develop independent learning and social skills of students through online learning. Learning independence and social skills can be formed when learners collaborate to identify information, models, and learning resources that are relevant to completing learning material.

Online learning and the presence of digital leaders are recognized as challenges in the 21st century. Even though people worldwide are saddened by the outbreak of Covid-19, which has forced the implementation of WFH policies, the application of online learning in the corridors of 21 st century digital higher education leaders still needs to be traced through scientific studies to get research. adequately (Darmalaksana, Wahyudin, and Hambali, 2020). 
The existence of the Covid-19 pandemic has provided another lesson, namely learning that is carried out at home so that it can make it easier for parents to monitor or supervise children's learning development directly. Parents also find it easier to guide and supervise children's learning at home. This will lead to more intensive communication and will lead to a closer relationship between children and parents. Parents can also provide direct guidance to children regarding learning material that is not understood by children. In online learning activities provided by the teacher, parents can see the extent of their children's competencies and abilities. Then if there is uncertainty in the material provided by the teacher, it will make communication between parents and children more well-established. Parents can help with learning difficulties in material faced by children.

\section{Use of Google Classroom and Zoom Course Management System in PBL-V}

In PBL-V activities, a web service that can be accessed and allows interaction between teachers and students is needed to support learning activities. The use of Google Classroom can be used, which is a free web service developed by Google for learning activities. The goal is to simplify the content of learning, distribute and assess assignments in a paperless manner. The main purpose of Google Classroom can be used to streamline the process of sharing files between teachers and students.

Based on the research results, the following data were obtained:

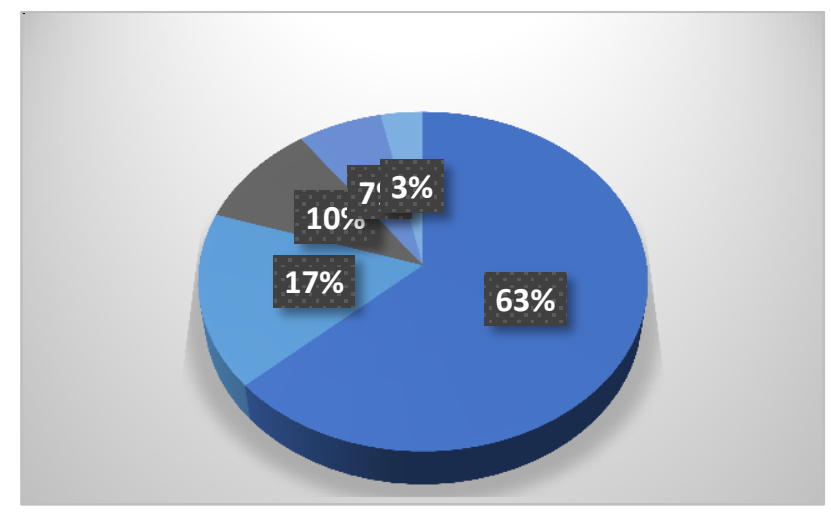

Figure 8. Student Response Diagram using Blended Learning

In Figure 8 it appears that most of the students feel Strongly Agree (63\%) using online learning during the Covid-19 pandemic. This condition is supported by most students who already have online learning facilities, including personal cellphones, laptops, even at their homes that have a wifi connection. This makes learning activities smooth online. Other data shows $17 \%$ of students agree and $10 \%$ of students say normal. This means that some students feel that sometimes the connection is constrained in the form of data packets. $7 \%$ stated that they did not agree, and 3\% of students stated that they strongly disagreed, this was because they did not have a cellphone or laptop, besides that there were also those whose cellphones were brought by working parents so they could not participate in learning activities.

Based on the results of the study, it shows that $63 \%$ of students strongly agree, and $17 \%$ of students agree with learning activities through blended learning during the Covid-19 pandemic. Moreover, using Google Classroom in online learning allows students to construct their understanding. Besides, it can maximize students to search for wider literature via the internet.

Using Google Classroom can be used easily where teachers can set up classes and invite students. There is a special class code, so it is safe to use. The Classwork page section is used to share information and assignments, questions, and materials. With Google Classroom, teachers can save time in learning. Besides, students also find it easier to find supporting literature. Students can view assignments on the Assignments page, in the class stream, or on the class calendar. All class materials are automatically stored in the Google Drive folder.

Besides, Google Classroom allows for more effective communication flow between teacher and student or between students. Teachers can make assignments or send announcements. The student's response in this study was the use of the Problem base learning virtually model in learning chemistry, as shown in the following diagram: 


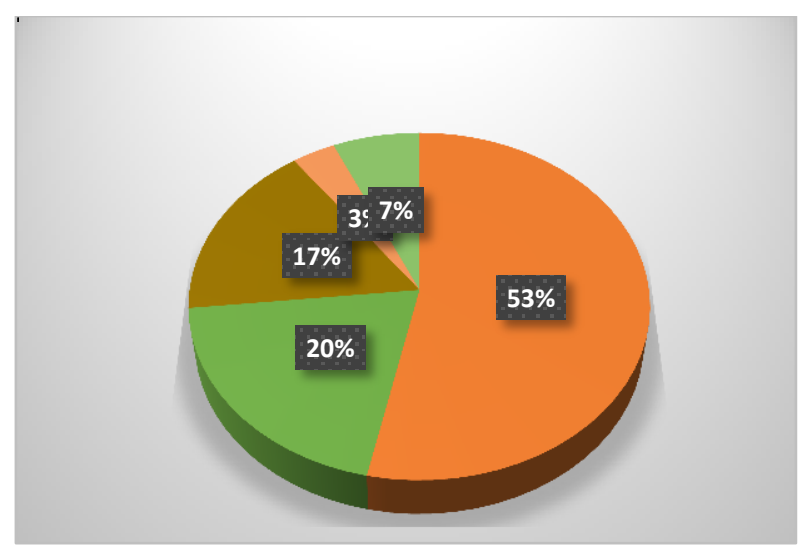

Figure 9. Student Response Diagram on PBL-V

In figure 9, it appears that many as 53\% of students felt Strongly Agree and $20 \%$ of students agreed with the use of PBL-V in the virtual teaching and learning of chemistry materials. This is because the material presented can easily be found for them to find literature and study any given theme with new experiences in learning. Increase the constructive ability of knowledge independently. As many as $17 \%$ of students feel normal, $3 \%$ disagree, and $7 \%$ strongly disagree. This is due to the difficulty of internet access; besides that, some said that they are still used to conventional learning so that students tend to be happy to receive information from the teacher rather than having to construct their understanding independently. The virtual environment involves many forms of media and materials that stimulate students' interest in learning and results in higher satisfaction.

\section{Strengths and weaknesses of the PBL-V Model}

Several things need to be studied about PBL-V, starting from its strengths to its weaknesses. This can be used as a reference for improving this learning model:

a) Advantages of the PBL-V Model

Some of the advantages of PBL-V are: it is easier for students to understand the concept that is constructed by themselves because they find the concept themselves, especially supported by the ease of accessing literature via online/online. The teacher directs the correct concept during the discussion. They involve students actively in solving problems and demanding higher thinking skills of learners. Students can feel the positive impact of learning because the problems that are solved are directly linked to real life, thereby increasing motivation to learn and arouse students' interest in the material being studied. Make learners more independent and mature, able to give aspirations, and accept opinions from others, instill a positive social attitude among learners.

b). Disadvantages of the PBL-V model

Some of the shortcomings include learning preparation (tools, problems, and concepts) which is complex, it is difficult to find relevant problems, misconceptions often occur, and it takes a long time. Sometimes there are internet network constraints for students in accessing literature in online learning activities.

\section{Research results that support the excellence of PBL-V}

Several studies that support PBL-V are in a scientific article by Phungsuk, Rojana, Viriyavejakul, Chantana entitled development of a problem-based learning model via a virtual learning environment states that:

The primary objective of this research was the development of a problem-based learning model using a virtual learning environment (VLE) for undergraduate students in the Photography for Communication Arts course. The model supports and enhances students' learning, achievements, and problem-solving skills. (Phungsuk et al., 2017). 
Show that the development of a problem-based learning model that uses virtual learning for undergraduate students so that it can support and improve learners' learning, achievement, and problemsolving skills. Another research in a scientific article entitled "The Effect of Virtual Media Assisted PBL Model on Physical Problem Solving Ability" shows that learning PBL model assisted by virtual media at the problem orientation stage at the beginning of learning, problems are presented through virtual media so that students are more motivated again in learning and easier to understand the concept with animations that are displayed through virtual media (Hastuti et al., 2017).

\section{PBL-V in Learning Chemistry Lessons}

Learning innovation during the Covid 19 pandemic needs to be done, so that teaching and learning activities continue to run well. The use of internet media or online learning greatly supports the teaching and learning process. The rationale for the importance of learners constructing their knowledge can still be combined with online learning.

PBL-V is one of the innovations that can be developed by teachers in teaching existing material in the curriculum. Learning objectives will be implemented, and a more complex literature study can support learning activities for learners. The use of supporting learning web media is also a major factor in the success of online learning activities. Like the use of Google Classroom and supported by face-to-face online using the Zoom application media is a good step in online teaching and learning activities.

Based on the description above, it can be concluded that learning activities during the Covid 19 pandemic required using online or online media so that the learning objectives were achieved. The PBL$\mathrm{V}$ model in blended learning activities is one way that can be developed in teaching learners to construct their knowledge which allows more literature study in the exploration of internet media. The results of this assessment indicate a positive response strongly agrees with as much as 53\% of the use of PBL-V in chemistry learning activities. As many as $63 \%$ of students stated that they strongly agreed with the use of blended learning with the offline composition: online $=10: 90$, which was carried out during the Covid-19 pandemic.

\section{CONCLUSION}

Based on the results of the analysis described above: Blended learning is very well applied in facilitating learners in constructing and exploring their knowledge. The existence of online meetings can make it easier for students to get more study references. Offline and online compositions can be adapted to conditions in the field. When online, you can also apply the use of virtual problem-based learning (PBLV), which is very good if it is applied to improve the ability of students independently.

\section{REFERENCES}

Budiaji, W. (2013). Skala Pengukuran dan Jumlah Respon Skala Likert (The Measurement Scale and The Number of Responses in Likert Scale). Ilmu Pertanian Dan Perikanan.

Darmalaksana, Wahyudin and Hambali, et all. (2020). Analisis Pembelajaran Online Masa WFH Pandemic Covid-19 sebagai Tantangan Pemimpin Digital Abad 21. Karya Tulis Ilmiah (KTI) Masa Work From Home (WFH) Covid-19 UIN Sunan Gunung Djati Bandung., 1-12. http://digilib.uinsgd.ac.id/30434/1/11042020 15.30 KTI.pdf

Desriyanti, R. D., \& Lazulva, L. (2016). Penerapan Problem Based Learning Pada Pembelajaran Konsep Hidrolisi Garam Untuk Meningkatkan Hasil Belajar Siswa. Jurnal Tadris Kimiya. https://doi.org/10.15575/jta.v1i2.1247

Fitriana, N. (2018). Penerapan Model Pembelajaran Blended Learning Pada Mata Kuliah Pemisahan Kimia Materi Kromatografi Untuk Meningkatkan Kualitas Belajar. Erudio Journal of Educational Innovation.

Hapsari, S. A., \& Pamungkas, H. (2019). Pemanfaatan Google Classroom Sebagai Media Pembelajaran Online Di Universitas Dian Nuswantoro. Wacana: Jurnal Ilmiah Ilmu Komunikasi. https://doi.org/10.32509/wacana.v18i2.924

Haqien, D., \& Rahman, A. A. (2020). Pemanfaatan Zoom Meeting Untuk Proses Pembelajaran Pada Masa Pandemi Covid-19. SAP (Susunan Artikel Pendidikan).

Hastuti, A., Sahidu, H., \& Gunawan, G. (2017). Pengaruh Model PBL Berbantuan Media Virtual Tehadap 
Kemampuan Pemecahan Masalah Fisika. Jurnal Pendidikan Fisika Dan Teknologi. https://doi.org/10.29303/jpft.v2i3.303

Hermawan, B. A., Wonorahardjo, S., \& Marfuah, S. (2017). Efektifitas Internet dalam Learning Cycle 6e pada Materi Hidrokarbon ditinjau dari Hasil Belajar Siswa. EduChemia (Jurnal Kimia Dan Pendidikan). https://doi.org/10.30870/educhemia.v2i2.1800

Indrawan, Rully, P. yaniawati. (2017). Metodologi Penelitian Kuantitatif, Kualitatif dan Campuran. PT. Refika Aditama.

Kusuma, J. W., \& Hamidah. (2020). Perbandingan Hasil Belajar Matematika Dengan Penggunaan Platform Whatsapp Group Dan Webinar Zoom Dalam Pembelajaran Jarak Jauh Pada Masa Pandemik Covid 19. Jurnal Ilmiah Pendidikan Matematika, 5 No. 1. https://doi.org/http://dx.doi.org/10.26877/jipmat.v5i1.5942

Phungsuk, R., Viriyavejakul, C., \& Ratanaolarn, T. (2017). Development of a problem-based learning model via a virtual learning environment. Kasetsart Journal of Social Sciences. https://doi.org/10.1016/j.kjss.2017.01.001

Praherdhiono, Henry, et all. (2020). Implementasi Pembelajaran Di Era Dan Pasca Pandemi Covid-19. CV. Seribu Bintang Malang.

Sari, Anggun Purnama, Ratu Betta Rudibyani, T. E. (2018). Efektivitas Problem Based Learning untuk Meningkatkan Keterampilan Berpikir Luwes Siswa pada Materi Asam Basa. Jurnal Pendidikan Dan Pembelajaran Kimia, 7 no.2.

Shofiyah, N., \& Wulandari, F. E. (2018). Model Problem Based Learning (Pbl) Dalam Melatih Scientific Reasoning Siswa. Jurnal Penelitian Pendidikan IPA. https://doi.org/10.26740/jppipa.v3n1.p33-38.

Sugiyono. 2015. Metode Penelitian Kuantitatif. Kualitatif dan R\&D. Bandung Alfabeta.

Sukmawati, S., \& Nensia, N. (2019). The Role of Google Classroom in ELT. International Journal for Educational and Vocational Studies. https://doi.org/10.29103/ijevs.v1i2.1526

Sulistiowati, N., Yuanita, L., \& Wasis, W. (2017). Perbedaan Penggunaan Laboratorium Real Dan Laboratorium Virtual Pada Keterampilan Proses Dan Hasil Belajar Siswa Materi Titrasi Asam Basa. JPPS (Jurnal Penelitian Pendidikan Sains). https://doi.org/10.26740/jpps.v2n2.p191-197

Tany, Y. S., \& Utami, T. H. (2006). Penerapan Problem Based Learning (PBL) untuk Meningkatkan Hasil Belajar Siswa. Penerapan Problem Based Learning.

Wijaya, A. (2016). Analysis of Factors Affecting the Use of Google Classroom to Support Lectures. International Conference on Information Technology and Engineering Application.

Wulandari, C. (2018). Estimasi Validitas Dan Respon Siswa Terhadap Bahan Ajar Multi Representasi : Definitif, Makroskopis, Mikroskopis, Simbolik Pada Materi Asam Basa. Phenomenon : Jurnal Pendidikan MIPA. https://doi.org/10.21580/phen.2018.8.2.2498

Wulandari, N. I., Wijayanti, A., \& Budhi, W. (2018). Efektivitas Model Pembelajaran Problem Based Learning Terhadap Hasil Belajar Ipa Ditinjau Dari Kemampuan Berkomunikasi Siswa. Jurnal Pijar MIPA. https://doi.org/10.29303/jpm.v13i1.538 